\title{
Western Zambian sable: Are they a geographic extension of the giant sable antelope?
}

\author{
Bettine Jansen van Vuuren ${ }^{1,2^{\star}}$, Terence J. Robinson ${ }^{1}$, Pedro VazPinto ${ }^{3}$, \\ Richard Estes ${ }^{4} \&$ Conrad A. Matthee ${ }^{1}$ \\ ${ }^{1}$ Evolutionary Genomics Group, Department Botany and Zoology, Stellenbosch University, \\ Private Bag X1, Matieland, 7602 South Africa \\ ${ }^{2}$ Centre for Invasion Biology, Department Botany and Zoology, Stellenbosch University, \\ Private Bag X1, Matieland, 7602 South Africa \\ ${ }^{3}$ Universidade Catolica de Angola, Rua Nossa Senhora da Muxima, 29 Luanda, Angola \\ ${ }^{4} 5$ Granite Street, Peterborough, NH 03458, U.S.A. \\ Received 5 September 2008. Accepted 21 January 2010
}

\begin{abstract}
The giant sable (Hippotragus niger variani) is one of Africa's most spectacular large antelope. Years of civil unrest in Angola, a highly localized distribution and interbreeding with its congener the roan antelope (H. equinus) has led to this subspecies being considered as critically endangered. Sable antelope occurring $\sim 600 \mathrm{~km}$ to the east in western Zambia superficially resemble giant sable in phenotype, prompting speculation in the popular media that the distribution of giant sable may be larger than currently documented. Our aim here was to investigate the evolutionary placement of western Zambian sable using mitochondrial DNA control region data. Phylogenetic analyses (maximum likelihood and Bayesian analyses) supported the monophyly of $H$. $n$. variani (Bayesian posterior probability of $>0.95$, bootstrap support $>80 \%$ ) and nested the western Zambian sable within $H$. n. niger. This finding was supported by an analysis of molecular variance that discretely grouped western Zambian sable from giant sable $\left(\Phi_{\mathrm{ST}}=0.645, P=0.001\right)$. Significant genetic structure was also found across the range of $H$. n. niger as indicated by our phylogenetic analyses and analysis of molecular variance $\left(\Phi_{\mathrm{ST}}=0.418, P=0.001\right)$. We conclude that although the western Zambian sable antelope and those of $\boldsymbol{H}$. $n$. variani resemble one another in morphology, particularly with respect to facial markings, significant genetic differences underpin these two evolutionary lineages. Our findings hold implications for the conservation of sable and highlight the need for active management intervention.
\end{abstract}

Key words: African antelope, Hippotragus niger variani, phylogenetic analyses.

\section{INTRODUCTION}

Ansell (1971) recognized four subspecies of sable antelope (Hippotragus niger) based on morphological characters (H.n. kirkii, H. n. roosevelti, H. n. niger and $H$. $n$. variani). A fifth subspecies $(H$. $n$. anselli), whose range is thought to extend from eastern Zambia to Malawi, is occasionally recognized (Groves 1983; Cotterill 2003). The preliminary genetic study conducted by Matthee \& Robinson (1999) which showed two well-delineated maternal lineages was extended by Pitra et al. (2002, 2006) using a far larger and geographically more representative sample. These authors confirmed the distinctness of the subspecific lineages based on morphology (Thomas 1916; Blaine 1922) although introgression of haplotypes at the boundary between $H_{\text {ron }} n$. kirkii and $H_{\text {a }}$ n. niger was documented in western Tanzania (at the localities of Rungwa, Ugalla, Kizigo and Wembere; Pitra et al. 2002).

Hippotragus $n$. variani (giant sable) was feared extinct as a result of more than 30 years of civil unrest in Angola. Intensive field efforts, camera trapping and genetic evidence (Pitra et al. 2006) confirmed their survival and persistence in central Angola. Giant sable are characterized by a distinct skull morphology (Blaine 1922), phenotypic differences that include the lack of a white stripe along the muzzle (Thomas 1916; Blaine 1922) and perhaps most strikingly, impressive horn length and shape compared to other sable antelope (Fig. 1A). In addition, mature $H$. n. variani males appear to be darkly pigmented (black) on the rump, albeit the distinction is based on a small sample of photographs (Silva 1972). Moreover, mature bulls retain brown hocks the same colour 

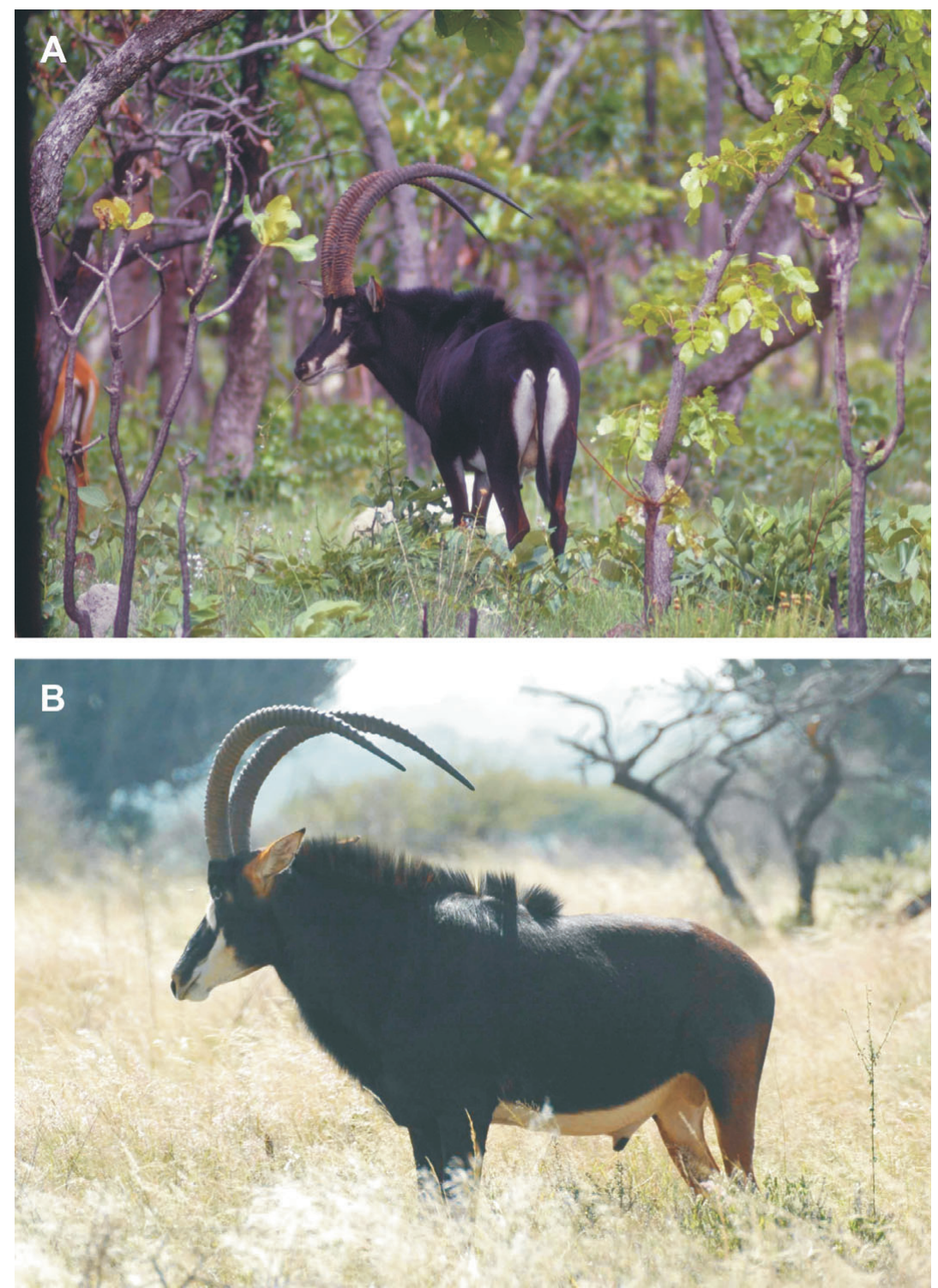

as the back of the ears (R.E., pers. obs.) and these features may, with more detailed examination, prove useful for distinguishing $H$. n. variani from other sable, particularly those in western Zambia.

Although conventionally considered to be restricted to the central part of Angola between the Cangandala National Park and the Luando Integral Nature Reserve, sightings of antelope resembling the giant sable have been reported over a much larger area (Estes \& Estes 1974; Cotterill 2003;
Crawford-Cabral \& Verissimo 2005). For example, sable occurring in the western part of Zambia close to the Angolan border occasionally resemble the giant sable in phenotype, most noticeably in facial markings and coat colour (see Fig. 1), prompting speculation in the popular press that these western Zambian sable antelope might be true $H$. n. variani (see Wessels 2007; McCallum 2008). If these antelope indeed prove to be giant sable, this would hold important implications for the conservation of $H$. n. variani. The subspecies 
is currently listed as critically endangered by the IUCN (revised in 2008) as a result of an $>80 \%$ decline in population size during the recent past, and an estimated population size of $<250$ individuals. Most recently, genetic introgression through hybridization with their congener, $H$. equinus (roan antelope) has been suggested as an even more pervasive threat (P.V., pers. obs.).

Assessing the geographic distribution of lineages based on phenotype alone is, however, misleading. The literature on phenotypic plasticity is complex, but it is commonly accepted that specific environments significantly affect phenotype (for reviews and discussion see Via et al. 1995; Trevor et al. 2003). However, just as phenotypic characters show variability due to differential selection across species' distributions, the converse also holds, i.e. that selection can constrain phenotypic variability despite underlying genetic differences (Tolley et al. 2006). Given that sable antelope from western Zambia show phenotypic characters that, at least superficially, appear to resemble those of the giant sable suggest (i) that the current localized distribution of the giant sable is incorrect or (ii), that the phenotypic similarity is misleading, and that genetic differences indeed sufficiently distinguish the populations justifying the uniqueness and conservation of $H$. n. variani. Our aim here was therefore to investigate the evolutionary placement of western Zambian sable within $H$. n. niger or H. n.variani based on genetic characters.

\section{METHODS}

Tissue from 10 sable antelope collected from western Zambia on the border with Angola (locality = Zambezi, $13^{\circ} 32^{\prime} \mathrm{S}, 23^{\circ} 06^{\prime} \mathrm{E}$ ) was provided by Oliver Coltman (at the time in the employ of Sable Ranch) as well as tissue from nine sable antelope collected from northwestern Zambia on the border with the Democratic Republic of the Congo (locality = Ikelenge, $11^{\circ} 14^{\prime} \mathrm{S}, 24^{\circ} 19^{\prime} \mathrm{E}$ ) provided by $\mathrm{P}$. Fisher (Nchila Wildlife Reserve). These specimens closely resemble the giant sable in facial markings and coat coloration (Fig. 1). DNA was extracted using a commercial extraction kit (Qiagen). The 5' side of the mitochondrial control region was amplified and sequenced using the primer combination L15926 and H00034 (Rosel et al. 1994). All laboratory protocols followed Jansen van Vuuren et al. (2002). Sequences were aligned to those generated in earlier studies (Pitra et al. 2002, 2006). Two roan antelope $(H$. equinus, GenBank accession numbers AF049373 and AF049374, Alpers et al. 2004), sister species to the sable, were included as outgroup. All specimens utilized in the present study are listed in Table 1.

Summary statistics, including haplotype and nucleotide diversities for sable antelope as a whole as well as for each of the subspecies, were calculated in Arlequin version 3.1 (Excoffier et al. 2005). Using specimens as OTUs, genealogical relationships were constructed under maximum likelihood (PAUP 4*, Swofford 2001) and Bayesian Inference (MrBayes 3.1.2, Ronquist \& Huelsenbeck 2003). For maximum likelihood, the optimal model of evolution $\left(H K Y+I_{0.276}+G_{0.621}\right)$ was determined with Modeltest 3.7 (Posada \& Crandall 1998) using hierarchical likelihood ratio test criteria. The robustness of the resultant topology was assessed by 500 bootstrap replicates (Felsenstein 1985). For the Bayesian analyses, five independent Markov chains were run on the Cornell University cluster for 10000000 generations with sampling at intervals of 100 generations. To ensure that the analyses were not trapped on local optima, the dataset was run twice and checked for convergence. The first $10 \%$ of all trees were discarded as burn-in (burn-in percentage was verified using the 'sump' parameter).

The spatial distribution of mitochondrial variation within $H$. n. niger ( $n=40$ individuals) was explored using an analysis of molecular variance (AMOVA implemented in Arlequin version 3.1, Excoffier et al. 2005). For this, $\Phi_{\text {ST }}$ was calculated considering H. n. nigeras a single group. To further explore whether the western Zambian sable (defined here by the animals from Sable Ranch and Nchila Wildlife Reserve) are genetically distinct from $H$. n. variani, western Zambian sable were defined as a population separate from the giant sable (defined as a population) and the distribution of variance determined.

\section{RESULTS}

A total of $474 \mathrm{bp}$ of control region sequence was included for each of 75 specimens taken from across the distribution of sable antelope. Fortythree haplotypes were found (Table 1). The majority of these were private (found in single specimens) with only 12 haplotypes shared between individuals. Haplotype $(h)$ diversity for sable antelope was calculated at 0.96 , reflecting the large number of unique haplotypes present in the sample. Haplotype and nucleotide $(\pi)$ diversities for the four different subspecies were: $H$. $n$. variani, $h=0.857, \pi=$ 
Table 1. Subspecies, maternal haplotypes and collection localities for 75 sable specimens collected from across the distribution range of the species (H. n. variani, $n=8 ; H$. n. niger, $n=40 ; H$. n. roosevelti, $n=9 ; H$. $n$. kirkii, $n=18)$. GenBank accession numbers: symbols denote sequences taken from Pitra (\$, Pitra et al. 2006; $\mathbf{2}$, Pitra et al. 2002); $\bullet$, sequences generated in the present study, available from B.J.v.V.).

\begin{tabular}{|c|c|c|c|}
\hline Subspecies & Haplotype & Collection locality & GenBank accession no. \\
\hline \multirow[t]{3}{*}{ H. n. variani } & $\mathrm{S} 1$ & $\begin{array}{l}\text { Luando, Angola } \\
\text { Cangandala, Angola } \\
\text { Cangandala, Angola } \\
\text { Cangandala, Angola } \\
\text { Luando, Angola }\end{array}$ & $\begin{array}{l}\text { ФAY970699 } \\
\text { ФAY970696 } \\
\text { ФAY970695 } \\
\text { ФAY970694 } \\
\text { ФAY875643 }\end{array}$ \\
\hline & S2 & Cuanza, Angola & АY 971590 \\
\hline & S3 & $\begin{array}{l}\text { Cuanza, Angola } \\
\text { Cuanza, Angola }\end{array}$ & $\begin{array}{l}\text { ФAY971591 } \\
\text { ФAY971589 }\end{array}$ \\
\hline \multirow[t]{20}{*}{ H. n. niger } & S4 & Wembere, Tanzania & AF364711 \\
\hline & S5 & Kafue, Zambia & AF364720 \\
\hline & S6 & Luangwa, Zambia & AAF364703 \\
\hline & S7 & Kafue, Zambia & NAF364706 \\
\hline & $\begin{array}{l}\text { S8 } \\
\text { S8 }\end{array}$ & $\begin{array}{l}\text { Ugalla, Tanzania } \\
\text { Ugalla, Tanzania }\end{array}$ & $\begin{array}{l}\text { AF364749 } \\
2 A F 3647\end{array}$ \\
\hline & S9 & Kizigo, Tanzania & AF364725 \\
\hline & S10 & Rufunsa, Zambia & AF364715 \\
\hline & S11 & Chobe, Botswana & AF364689 \\
\hline & S12 & Chobe, Botswana & \&AF364746 \\
\hline & S13 & Chobe, Botswana & AF364700 \\
\hline & $\mathrm{S} 14$ & $\begin{array}{l}\text { Triangle, Zimbabwe } \\
\text { Mahango, Namibia } \\
\text { Triangle, Zimbabwe }\end{array}$ & $\begin{array}{l}\text { AF364710 } \\
\text { \&AF364770 } \\
\text { \&AF364698 }\end{array}$ \\
\hline & S15 & Chobe, Botswana & AF364691 \\
\hline & S16 & Chobe, Botswana & AF364693 \\
\hline & $\mathrm{S} 17$ & Luangwa, Zambia & \&AF364702 \\
\hline & S18 & Triangle, Zimbabwe & AF364699 \\
\hline & S19 & Olifantsfontein, South Africa & AF049367 \\
\hline & $\mathrm{S} 20$ & $\begin{array}{l}\text { Olifantsfontein, South Africa } \\
\text { Pilansberg Game Reserve, South Africa }\end{array}$ & $\begin{array}{l}\text { \&AF049366 } \\
\text { \&AF049368 }\end{array}$ \\
\hline & $\mathrm{S} 21$ & $\begin{array}{l}\text { Zambezi, Zambia } \\
\text { Zambezi, Zambia } \\
\text { Zambezi, Zambia } \\
\text { Zambezi, Zambia } \\
\text { Zambezi, Zambia } \\
\text { Zambezi, Zambia } \\
\text { Zambezi, Zambia } \\
\text { Zambezi, Zambia } \\
\text { Zambezi, Zambia } \\
\text { Zambezi, Zambia }\end{array}$ & $\overrightarrow{<}$ \\
\hline & S22 & $\begin{array}{l}\text { Ikelenge, Zambia } \\
\text { Ikelenge, Zambia } \\
\text { Ikelenge, Zambia }\end{array}$ & $\bullet$ \\
\hline & S23 & $\begin{array}{l}\text { Ikelenge, Zambia } \\
\text { Ikelenge, Zambia } \\
\text { Ikelenge, Zambia } \\
\text { Ikelenge, Zambia } \\
\text { Ikelenge, Zambia } \\
\text { Ikelenge, Zambia }\end{array}$ & $\begin{array}{l}\vec{े} \\
\vec{े} \\
\vec{े}\end{array}$ \\
\hline H. n. roosevelti & S24 & $\begin{array}{l}\text { Shimba-hills, Kenya } \\
\text { Shimba-hills, Kenya }\end{array}$ & $\begin{array}{l}\text { AF364686 } \\
\text { AF364685 }\end{array}$ \\
\hline
\end{tabular}




\begin{tabular}{|c|c|c|c|}
\hline Subspecies & Haplotype & Collection locality & GenBank accession no. \\
\hline & $\mathrm{S} 25$ & Songea, Tanzania & AF364772 \\
\hline & S26 & Selous, Tanzania & AF364759 \\
\hline & S27 & Selous, Tanzania & AF364766 \\
\hline & $\mathrm{S} 28$ & Sadani, Tanzania & AF364771 \\
\hline & S29 & Shimba Hills, Kenya & AF364769 \\
\hline & S30 & $\begin{array}{l}\text { Selous, Tanzania } \\
\text { Selous, Tanzania }\end{array}$ & $\begin{array}{l}\text { \&AF364767 } \\
\text { \&AF364717 }\end{array}$ \\
\hline \multirow[t]{13}{*}{ H. n. kirkii } & S31 & Ugalla, Tanzania & AF364750 \\
\hline & S32 & Niensi, Tanzania & AF364756 \\
\hline & S33 & Rungwa, Tanzania & \&AF364763 \\
\hline & S34 & $\begin{array}{l}\text { Kigosi, Tanzania } \\
\text { Kigosi, Tanzania }\end{array}$ & $\begin{array}{l}\text { \&AF364753 } \\
2 A F 364741\end{array}$ \\
\hline & S35 & Ugalla, Tanzania & AF364744 \\
\hline & S36 & Wembere, Tanzania & AF364734 \\
\hline & S37 & Ugalla, Tanzania & AF364754 \\
\hline & S38 & $\begin{array}{l}\text { Ugalla, Tanzania } \\
\text { Wembere, Tanzania } \\
\text { Niensi, Tanzania } \\
\text { Kizigo, Tanzania }\end{array}$ & $\begin{array}{l}\text { NAF364745 } \\
\text { \$AF364761 } \\
\text { \$AF364692 } \\
\text { \$AF364727 }\end{array}$ \\
\hline & S39 & $\begin{array}{l}\text { Rungwa, Tanzania } \\
\text { Rungwa, Tanzania }\end{array}$ & $\begin{array}{l}\text { AF364762 } \\
\text { \&AF364758 }\end{array}$ \\
\hline & S40 & Kizigo, Tanzania & AF364732 \\
\hline & S41 & Ugalla, Tanzania & AF364735 \\
\hline & S42 & Kizigo, Tanzania & AF364724 \\
\hline & S43 & Niensi, Tanzania & AFF64728 \\
\hline
\end{tabular}

$0.00397 ; H . n$. niger, $h=0.919, \pi=0.0491 ; H . n$. roosevelti, $h=1, \pi=0.0367 ; H$. $n$. kirkii, $h=0.995$, $\pi=0.0177$. Importantly, no haplotypes were shared among the subspecies.

Maximum likelihood and the Bayesian analyses retrieved similar topologies, and the combined Bayesian tree is shown in Fig. 2. The monophyly of all subspecies, with the exception of $H$. n. niger, was supported with high posterior probability and bootstrap support. As with previous studies $H$. $n$. niger and $H$. n. variani were not reciprocally monophyletic, and this is discussed in more detail below (see also Pitra et al. 2006). Importantly, the western Zambian specimens consistently grouped separately from $H$. n. variani irrespective of the method of analysis.

Within $H$. n. niger, some geographic structure was evident from our phylogenetic analyses (see also Pitra et al.2006). Sable from the southern part of Tanzania (Wembere, Ugalla and Kizigo) grouped most closely to the giant sable. Sable from southern Africa (Botswana, Namibia, Zimbabwe and South Africa) were clustered together while sable from Kafue and Luangwa in Zambia grouped together.
Three haplotypes were identified for the 19 specimens included from western Zambia; the 10 individuals from Zambezi (Sable Ranch) all shared a single haplotype with two haplotypes characterizing specimens from Ikelenge (Nchila Wildlife Reserve). One of these haplotypes identified from Ikelenge grouped with haplotypes from Kafue and Luangwa, Zambia (see Fig. 2).

An analyses of molecular variance confirmed significant partitioning of genetic variation within $H$. n. niger with $42 \%$ of the variance $\left(\Phi_{\mathrm{ST}}=0.418\right.$, $P<0.001)$ explained by differences among geographic sampling locations (southern Tanzania as defined by Wembere, Ugalla and Kizigo; Zambia as defined by Kafue and Luangwa; southern Africa as defined by populations in Namibia, Zimbabwe and Botswana and South Africa; and western Zambia as defined by Zambezi and Ikelenge). When the giant sable population was compared against western Zambian sable (Zambezi and Ikelenge), the majority of the variance was between these groups $\left(\Phi_{\mathrm{ST}}=0.645, P<0.001\right)$ confirming that the western Zambian sable do not belong to $H$. n. variani. 


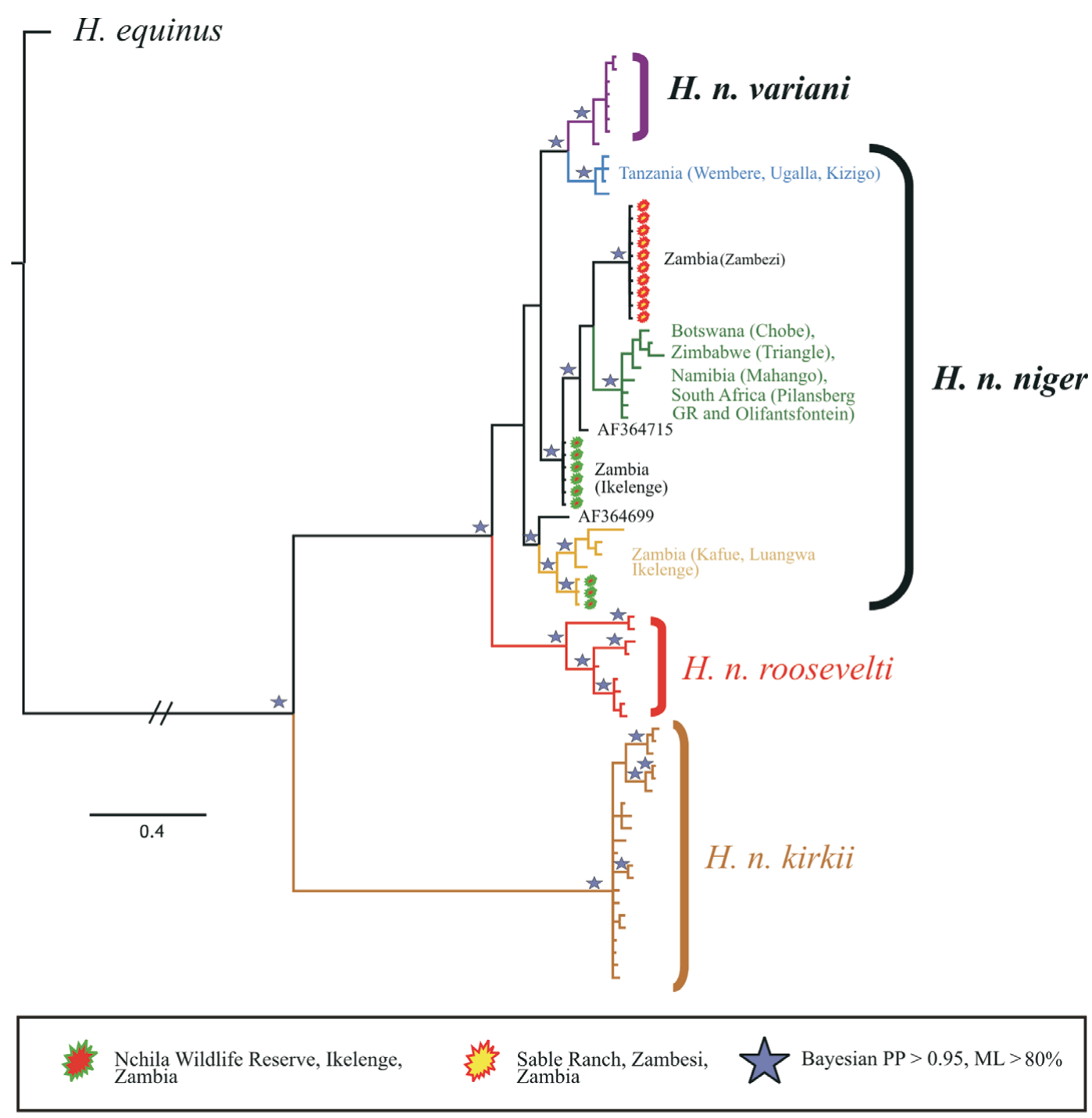

\section{DISCUSSION}

Our results and those of Pitra et al. $(2002,2006)$ indicate significant partitioning of genetic variation in sable antelope across their pan-African distribution. Genetic groupings retrieved in these studies broadly conform to recognized subspecies boundaries (Ansell 1971) but indicate some admixture among taxa in western Tanzania (for more detail see Pitra et al.2002). Although H. n. niger and H. n. variani are not reciprocally monophyletic in our analyses $(H . n$. variani clusters within $H$. n. niger) this association can be explained by coalescence theory. The time needed from lineage divergence to reciprocal monophyly is largely dependent on the effective population size (or number of reproductive individuals) in the two groups (see Nei \& Takahata 1993). The effective population size in giant sable is significantly smaller than in $H$. $n$. niger and it follows that $H$. n. variani would reach monophyly much earlier than $H$. $n$. niger. Therefore, notwithstanding that these two groups have not fully diverged (i.e. are not reciprocally monophyletic), there is overwhelming genetic evidence that both represent distinct evolutionary lineages. 
The distribution of sable antelope across Africa closely follows the miombo woodland. Although large geographic areas of Angola comprise this vegetation type, Estes \& Estes (1974) argued that there is no real evidence to suggest that giant sable ever occurred outside of a few small isolated areas, most notably the Cangandala National Park and Luando Integral Nature Reserve (see also the earlier report by Blaine (1922), who suggested that giant sable are isolated by 'natural boundaries' from southern sable). However, as Estes \& Estes (1974) pointed out, 'lack of evidence is no proof that the giant sable was not once found in a broader range'. In fact, they mentioned reports of sable antelope $175 \mathrm{~km}$ east and west of the Luando Reserve, but these claims were never confirmed (Crawford-Cabral \& Verissimo 2005). Should giant sable have extended their natural range southeastwards into Zambia (or alternatively, that western Zambian sable extended their range into Angola as suggested by CrawfordCabral \& Veríssimo (2005)), there is no doubt that inter-breeding would have occurred and the legacy of this should be evident in the DNA profiles of both populations (as was detected between H. n. niger and H. n. kirkii by Pitra et al. (2002)).

There has been speculation in the popular literature (Wessels 2007; McCallum 2008) that sable antelope found in western Zambia might be giant sable (H.n. variani) and not, as convention holds, $H$. n. niger. Our phylogenetic results clearly demonstrate that the western Zambian sable, although superficially resembling the giant sable in phenotype, are not referable to $H$. n. variani. This is further supported by the horn length of animals from western Zambia. The minimum trophy size stipulated by Rowland Ward for giant sable is 56 inches $(142 \mathrm{~cm})$, and no single specimen equal to, or in excess of this has, with the exception of a single trophy specimen hunted in 1931 in the Democratic Republic of the Congo, ever been reported outside of Angola.

Whether H. n. niger $\times H$. n. variani hybrids exist in this area cannot be determined since only mitochondrial DNA sequences were included in our analysis. Importantly, however, none of the haplotypes detected in the western Zambian sable specimens were shared with those from Angola, nor were $H$. n. niger haplotypes detected in the Angolan population. This result would require consistent unidirectional introgression (male Angolan sable into western Zambian herds or western Zambian males into Angolan sable herds), an unlikely outcome given the limited movement and territorial behaviour documented for sable antelope (Estes \& Estes 1974). A nuclear study (VazPinto et al., unpubl. data) is currently under way to further investigate these aspects of sable biology.

Finally, there is plasticity in the characters (for example facial markings) that are conventionally used to distinguish the giant sable from other sable, thus questioning their usefulness as robust indicators of taxonomic relationships. This clearly begs a more detailed examination of phenotypic variation throughout the species' range. Importantly, however, it is neither the horn-length nor the facial markings of giant sable that are driving conservation concerns, but rather its unique evolutionary history and the threat posed by introgression. Our findings underscore the need for renewed and intensified conservation efforts to ensure the survival of the giant sable in Angola. Without immediate and direct intervention the future of this spectacular antelope remains bleak.

\section{ACKNOWLEDGEMENTS}

Piet Eloff and Louw Hoffmann are thanked for help with compiling the list of references and Sandi Willows-Munro for technical assistance. Peter Henry Fisher and the late Oliver Coltman provided material from western Zambian sable antelope. Kobus du Toit is thanked for providing information regarding the western Zambian animals used in our investigation. Brian Huntley kindly provided access to J.A. Silva's thesis. Our manuscript was greatly improved by the comments from two anonymous referees. Part of this work was carried out by using the resources of the Computational Biology Service Unit from Cornell University which is partially funded by Microsoft Corporation. Photograph credits: Kobus du Toit, Richard Estes.

\section{REFERENCES}

ALPERS, D.L., JANSEN VAN VUUREN, B., ARCTANDER, P. \& ROBINSON, T.J. 2004. Population genetics of the roan antelope (Hippotragus equinus) with suggestions for conservation. Mol. Ecol. 13: 1771-1784.

ANSELL, W.F.H. 1971. Order Artiodactyla. In: J. Meester, H.W. Setzer (Eds), The mammals of Africa: an identification manual (pp. 15-83). Smithsonian Institution, Press, Washington.

BLAINE, G. 1922. Notes on the zebras and some antelopes of Angola. Proc. Zool. Soc. Lond.pp. 317-339.

COTTERILL, F.P.D. 2003. Geomorphological influences on vicariant evolution in some African mammals in the Zambezi Basin: some lessons for conservation. In: A. Plowman (Ed.), Ecology and conserva- 
tion of small antelope (pp. 11-58). Filander Verlag, Furth.

CRAWFORD-CABRAL, J. \& VERÍSSIMO, L.N. 2005. The ungulate fauna of Angola: systematic list, distribution maps, database report. Estudos, Ensaios e Documentos 163. Ministerio da Ciência Tecnologia e Ensio Superior, Lisbon, Portugal.

ESTES, R.D. \& ESTES, R.K. 1974. The biology and conservation of the giant sable antelope, Hippotragus niger variani Thomas, 1916. Proc. Natl. Acad. Sci. USA 126: 73-104.

EXCOFFIER, L., LAVAL, G. \& SCHNEIDER, S. 2005. Arlequin ver. 3.0: an integrated software package for population genetics data analysis. Evol. Bioinfor. Online. 1: 47-50.

FELSENSTEIN, J. 1985. Confidence limits on phylogenies: An approach using the bootstrap. Evolution 39: 783-791.

GROVES, C. P. 1983. A new subspecies of sable antelope, Hippotragus niger (Harris 1938). Rev. Zool. Afr. 97: 821-828.

JANSEN VAN VUUREN, B., BEST, P.B., ROUX, J.P. \& ROBINSON, T. 2002. Phylogeographic population structure in the Heaviside's dolphin (Cephalorhynchus heavisidii): conservation implications. Anim. Conserv. 5: 303-307.

MATTHEE, C.A. \& ROBINSON, T.J. 1999. Mitochondrial DNA population structure of roan and sable antelope: implications for the translocation and conservation of the species. Mol. Ecol. 8: 227-238.

McCALLUM, A. 2008. Royal sable. African Outfitter June/July pp. 26-28.

NEI, M. \& TAKAHATA, N. 1993. Effective population size, genetic diversity, and coalescence time in subdivided populations. J. Mol. Evol. 37: 240-244.

PITRA, C., HANSEN, A.J., LIECKFELDT, D. \& ARCTANDER, P. 2002. An exceptional case of historical outbreeding in African sable antelope populations. Mol. Ecol. 11: 1197-1208.
PITRA, C., VAZPINTO, P., O'KEEFFE, B.W.J., WILLOWSMUNRO, S., JANSEN VAN VUUREN, B. \& ROBINSON, T.J. 2006. DNA-led rediscovery of the giant sable antelope in Angola. Eur. J. Wildl. Res. 52 145-152.

POSADA, D. \& CRANDALL, K.A. 1998. Modeltest: testing the model of DNA substitution. Bioinformatics. 14: 817-818.

RONQUIST, F. \& HUELSENBECK, J.P. 2003. MrBayes 3: Bayesian phylogenetic inference under mixed models. Bioinformatics 19: 1572-1574.

ROSEL, P.E., DIZON, A.E. \& HEYNING, J.E. 1994 Genetic analysis of sympatric morphotypes of common dolphins (genus Delphinus). Marine Biol. 119: 159-167.

SILVA, J.A. 1972. Contribuição para estudo bioecolócico da Palanca Real (Hippotragus niger varianı). Junta de Investigacoes do Ultamar. CDU 599.73 (673). Pp. 116 excluding figures and appendices.

SWOFFORD, D.L. 2001. PAUP*: hylogenetic analysis using parsimony (*and other methods) Sinauer Associates, Sunderland, Mass.

THOMAS, O. 1916. Hippotragus niger variani Thomas, 1916. Proc. Zool. Soc. Lond. pp. 298-301.

TOLLEY, K.A., BURGER, M., TURNER, A.A. \& MATTHEE, C.A. 2006. Plio-Pleistocene climate shifts shape biogeographic patterns of dwarf chameleons (Bradypodion) in the Cape Floristic Region of South Africa. Mol. Ecol. 15: 781-793.

TREVOR, D.P., ANNA, Q.\& DARREN, E.I. 2003. The role of phenotypic plasticity in driving genetic evolution. Proc. R. Soc. Lond. B 270: 1433-1440.

VIA, S., GOMULKIEWICZ, R., DEJONG, G., SCHEINER, S.M., SCHLICHTING, C.D. \& VANTIENDEREN, P.H. 1995. Adaptive Phenotypic plasticity - Consensus and controversy. TREE 10: 212-217.

WESSELS, J. 2007. Western Zambian sable: a giant sable look-alike or the real thing? Game \& Hunt November: 32-36. 